\title{
FACTORS DETERMINING THE PHENOMENA IN THE UPER TREE LINE ECOTONE IN THE POLAR URALS MOUNTAINS
}

\author{
V. V. FOMIN - Doctor of Biological Sciences, \\ Vice-rector for Research, Innovation and Digital transformation ${ }^{1}$, \\ phone: +79022723408 , \\ e-mail: fominvv@m.usfeu.ru \\ ORCID: 0000-0002-9211-5627; \\ S. G. SHIYATOV - Doctor of Biological Sciences, Professor, \\ Chief Scientific Researcher ${ }^{2}$, \\ phone: +79126161570 , \\ e-mail: stepan@ipae.uran.ru \\ ORCID: 0000-0003-0402-335X \\ ${ }^{1}$ FSBEE HE «Ural State Forestry University», \\ 620100, Russia, Yekaterinburg, Sibirian trakt, 37 \\ ${ }^{2}$ Institute of Plant and Animal Ecology UB RAS, \\ 620144, Russia, Yekaterinburg, 8 Marta, 202
}

Reviewer: Zalesov S. V., Doctor of Agricultural Sciences, Professor of the Forestry Department of the Ural State Forestry University.

Keyworld: landscape photographs, treeline ecotone, climate driven change, anthropogenic impact, Polar Urals, Russia.

The article presents the results of the analysis of long-term studies dedicated to the reaction of woody plants to various extreme factors in the Rai-Iz mountain massif and Chernaya mountain, which are located on the southeastern slope of the Polar Urals in the Sob River basin (Russia). The analysis was performed using a unique archive of landscape photos, which were made by the authors from the beginning of the 1960 s until the present. The classification and description of the phenomena that are caused by the influence of environmental factors on woody vegetation, as well as their presentation using landscape photos, allow us to expand the possibilities of using ground-based images for the purposes of environmental photo monitoring of woody vegetation at the tree line. They can be used as an independent data source to identify factors that determine a morphological structure and spatial altitude of woody vegetation.

\section{Introduction}

Mountain systems are characterized by a wide variety of environmental conditions that make an impact on trees and shrubs, especially in the uPer tree line ecotone (UTLE). An uPer boundary of the distribution of solitary woody plants and an uPer boundary of a closed forest are the uPer and lower boundaries of the UTLE, correspondingly. Forest-tundra ecosystems are widespread in the UTLE in the Polar Urals. They are characterized by different species composition, morphological and age structures, which are of great interest for studying ways of adaptation of woody plants to various extreme environmental conditions.

When describing phenomena that are associated with the in- fluence of environmental factors on woody vegetation growing at the uPer boundary of its distribution, landscape photos are often used as illustrations [1-7]. In some cases, one or several photos can be associated with the same phenomenon [8-10]. Despite some successes in the development of methods for automated image segmentation, recognition of objects 
and scenes in landscape photos [11-12]. the task of their automated and, moreover, automatic recognition of objects on them without preliminary creation of classification by a researcher, is practically impossible now.

Therefore, it is necessary to develop classifications of landscape photos by the presence and degree of manifestation of phenomena caused by the influence of extreme environmental conditions as part of the development of a ground-based photo monitoring method, which is increasingly used by specialists in environmental research. The need for this type of work is caused by the following reasons: 1) the need to take into consideration the regional specifics of the research area; 2) the need to illustrate and describe non-obvious phenomena caused by the impact of environmental factors on woody vegetation; 3) the need to specialize and formalize descriptions of landscape photos to increase the effectiveness of their full-text search in information system databases.

The article presents the results of multi-year research of Siberian larch reaction to various extreme factors in the Sob River basin in the Rai-Iz mountain massif and Chernaya mountain, which belong to the southeast macroslope of the Polar Urals.

The purpose of the article is to analyze the influence of environmental factors on the morphological structure and distribution of Siberian larch at the uPer tree line growth in the Polar Urals mountains and to present the effects that visually aPear in landscape photos.

\section{Objects and methods}

Research area: the Rai-Iz mountain massif and Chernaya mountain, which are located in the southeast macroslope of the Polar Urals in the Sob River basin (Fig. 1). Coordinates of the research area: $66^{\circ} 42^{\prime}-$ $67^{\circ} 48^{\prime} \mathrm{N} ; 65^{\circ} 08^{\prime}-65^{\circ} 04^{\prime} \mathrm{E}$.
The maximum elevations of these mountains exceed $1,000 \mathrm{~m}$, and the uPer tree line ecotone is located at heights of 100 to $450 \mathrm{~m}$. Siberian larch (Larix sibirica Ldb.) mainly grows within the ecotone. Mountain birch (Betula tortuosa Ldb.) and Siberian spruce (Picea
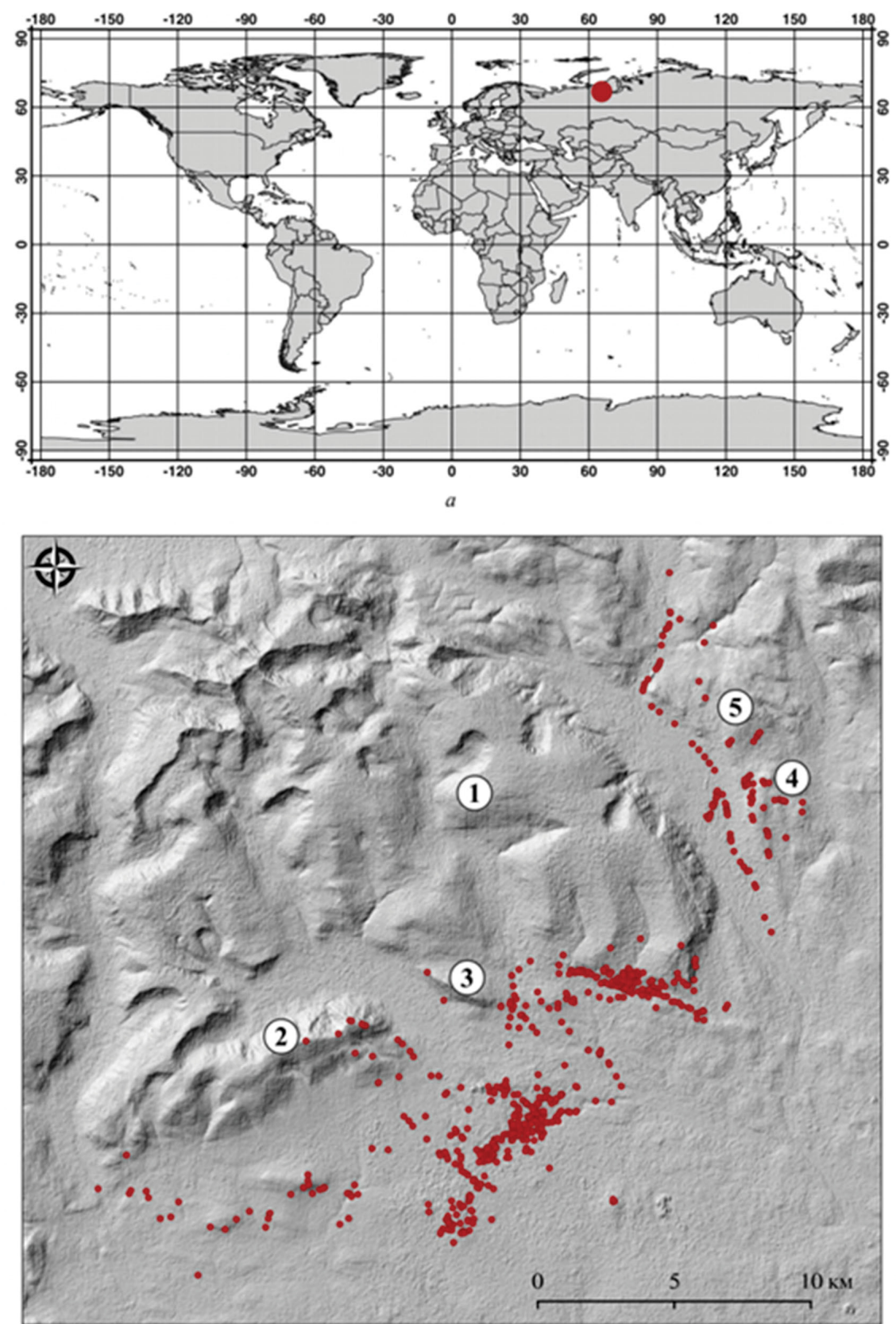

b

Fig. 1. The location of the research area on the world map $(a)$. The shadow relief model of the research area $(b)$ : the location of the photographic survey points; the large geomorphological structures are indicated with numbers:

1 - the Rai-Iz mountain massif; 2 - Chernaya mountain; 3 - Malaya Chernaya mountain; 4 - Slantsevaya mountain; 5 - Yar-Keu mountain 
obovata L.) are found in a small amount here. The photos taken by us in different years are used as illustrations in the article.

The photos that make up the core of the archive were taken over different years using cameras produced by the following companies: Krasnogorsk Mechanical Plant (USSR), Yashica (Japan) (using standard black-and-white and color photographic films of $36 \mathrm{~mm} \times 24$ ), as well as Canon (Japan), and Sony (Japan) (using files in the digital format).

The creation of a map of the research area with photographic survey points was made in the QGIS geographical information system (qgis.org). AsterDem (USGS, USA) was used as a digital terrain model.

\section{Results and its discussion}

\section{Air temperature}

The main factor determining the uPer tree line growth in the Polar Urals is the thermal regime of sur- face air in the summer. On smooth slopes (up to 15-20 degrees), where the unweathered rock is covered with a layer of soil or finegrained soil, the uPer boundary of the forest-tundra sparse forest growth rises the highest - up to 300-350 meters above sea level. On such slopes, woody vegetation forms the thermal type of the uPer tree line. Due to the fact that steep and rocky slopes prevail in the research area, the distribution of the thermal type boundary is insignificant; it is mainly located on the southeastern slope of the Rai-Iz mountain massif. A specific feature of the thermal type is its constant altitude displacement due to the long-term and medium-term climatic fluctuations. The thermal boundary of sparse forests rises higher along the slope in warm periods, and it shifts to lower hypsometric levels in cold periods.

The two landscape photos taken from the same point of photography with an interval of 19 years are shown in fig. 2. They demonstrate that the emergence of a new generation of trees occurs both in the lower (in the far-distance view) and in the uPer (in the short- and middle distance views) sections of the Rai-Iz mountain massif. Fig. 2 clearly demonstrates that at the present time, due to climate warming, larch is being intensively disseminated into tundra biocoenoses. The sparse larch forest grew on this sloping site during the Medieval climate warming (600-800 years ago), but it completely died out during the cooling in the Little Ice Age (600-150 years ago). Only remnants of trunks and roots of these trees have been preserved up to the present day. Over the past millennium, the uPer boundary of sparse forests on this slope shifted between 340 and $140 \mathrm{~m}$ above sea level [3].

\section{Wind regime}

Strong westerly winds, especially in the winter, are characteristic

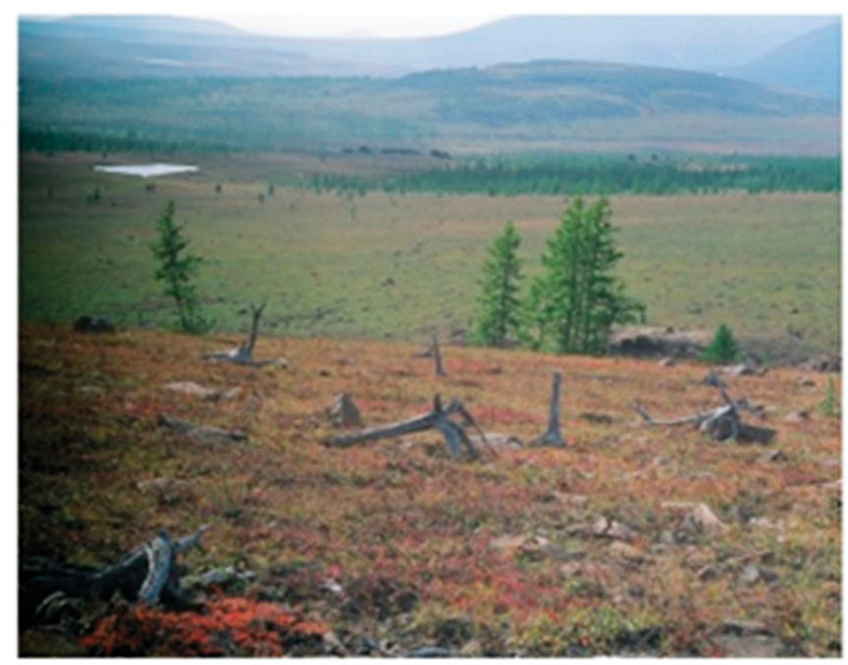

$a$

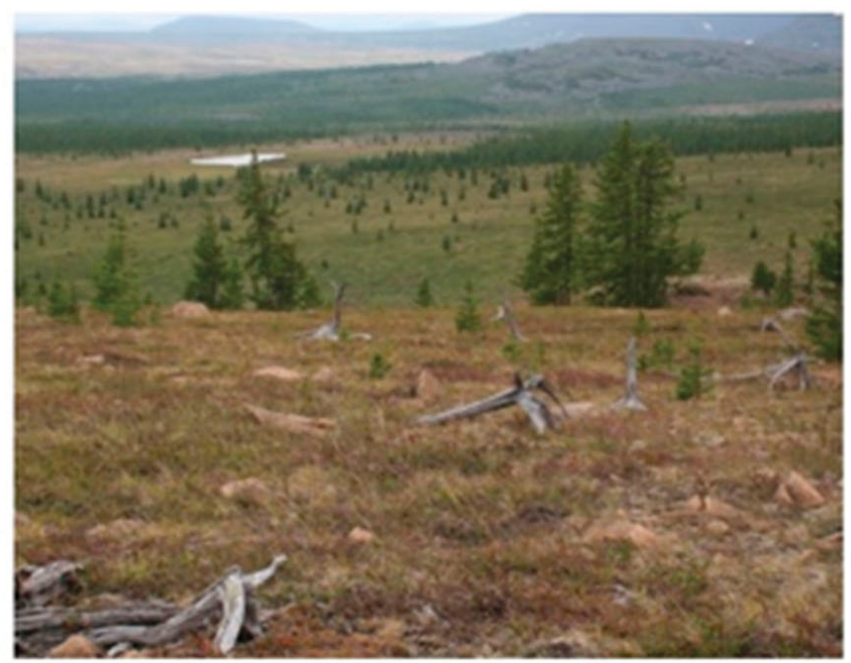

$b$

Fig. 2. The landscape photos illustrating the aPearance of the young generation of Siberian larch in the lower and uPer parts of the southeastern macro slope of the Rai-Iz mountain massif. The photos were taken by S. G. Shiyatov on August 08, 1996 (a) and V. V. Fomin on August 1, 2015 (b) 
for the Polar Urals; they have a significant effect on the morphogenesis and vital state of larch. In the area of our research, especially strong winds (up to $40 \mathrm{~m} / \mathrm{s}$ ) are observed in latitudinal sections of the Sob and Yenga-Yu Rivers valleys and on the tops of mountains. The wind has a great influence on the renewal and morphogenesis of woody plants. In strongly windy sites of slopes, larch has a
suPressed aPearance represented by dwarfs (Fig. 3a) and multi-stem forms (fig. 3b). The presence of a flag-shaped crown and the absence of side branches in the snow drifting zone of up to $1 \mathrm{~m}$ high
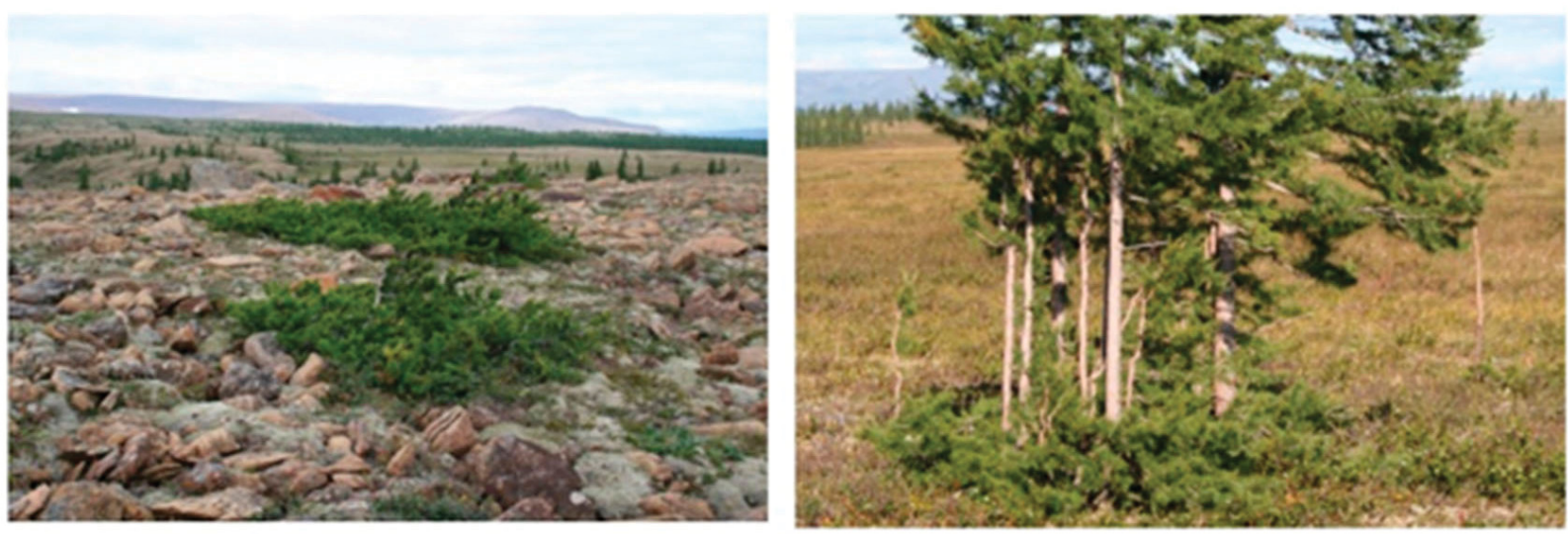

$a$
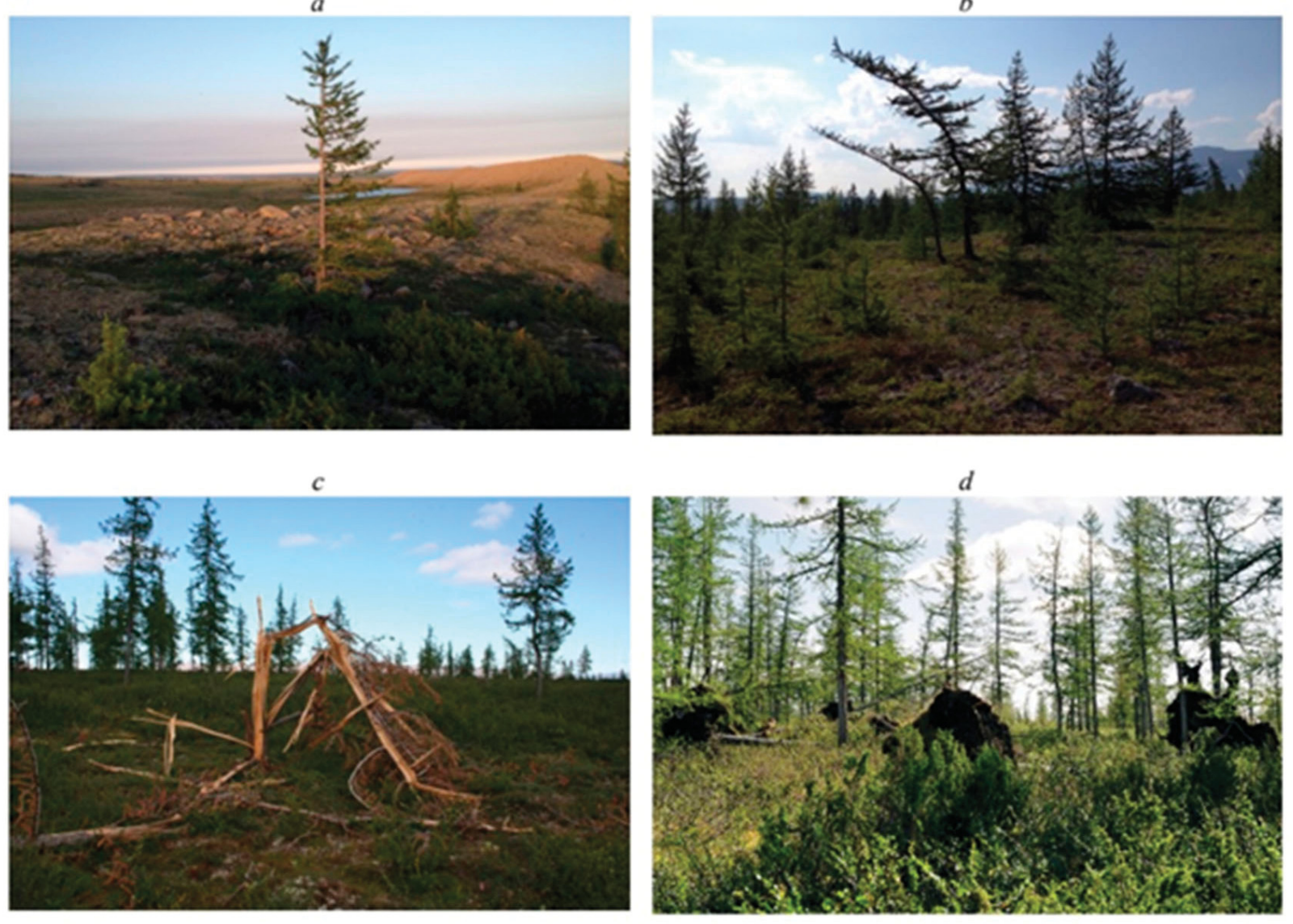

e

Fig. 3. The photos illustrating the phenomena caused by the influence of the wind and the intensification of cyclonic phenomena:

$a$ - larch of a dwarf form growing in a wind-breaking habitat on the top of the moraine line; $b$ - snow corrasion of larch trunks of a multi-stem forms; $c$ - a flag-shaped crown of Siberian larch formed as a result of wind and snow exposure in the winter (snow corrasion); $d$-curved tree trunks under long-term wind exposure; $e-$ the consequents of a lightning stroke on larch; $f$ - windfalled trees 
from the surface of the snow cover are the characteristic signs of wind exposure and snow corrasion (fig. 3b, 3c). In the windbreaking sections of the slope, the uPer boundary of sparse larch forests decreases compared to the areas protected from strong winds. Tree trunks of arched shape can be formed under the constant strong influence of the wind. An increase in the density of trees reduces the level of wind exposure on trees located in the depths of the forest area. This leads to the formation of the forest stand with curved trunks in old trees that grew in open areas with low tree density, and younger trees with straight trunks that grow under the protection of the old ones (Fig. 3d).

Due to modern climate warming, the height of trees growing in the ecotone increased significantly, and their crowns became more dense and voluminous. This means that crown sailing increased. At the same time, the number and power of cyclonic processes accompanied by strong winds and thunderstorms increased (Fig. 3e). This led to the fact that windfallen trees became more intense phenomena, especially on the uPer boundaries of sparse forests (Fig. 4f). Since trees have a superficial root system, quite a large spot forms on the site of a fallen tree, the surface of which is covered with a stone field or fine-grained soil. Such spots are slowly overgrown with vegetation, which reduces the productivity of forest-tundra ecosystems. Solitary tree falls prevail, but group tree falls are also found in some sections of slopes (Fig. 4f).

\section{Snow cover, snow avalanches} breaking up of ice on a river

Snow cover is the most important environmental factor for the woody vegetation growth in the northern mountainous regions. The Polar Urals is characterized by an uneven distribution of the snow cover thickness due to the transfer of snow by wind. Snow is blown away from the elevated and wind-breaking sections of the slope. The snow cover thickness is only $10-30 \mathrm{~cm}$ in these areas, and snowdrifts with a thickness of up to 6-10 $\mathrm{m}$ are deposited in topographic lows and islets of sparse forests (Fig. 4a). Snow cover has both positive and negative effects on woody vegetation in the forest-tundra ecotone. In habitats with a small amount of snow (up to $30 \mathrm{~cm}$ ), uPer shoots not covered by snow dry out under the influence of snow corrasion and low temperatures. A certain amount of such undergrowth turns into a dwarf. Only lignified shoots are preserved; it is usually observed after a warm and longer vegetation period. Snow cover with a thickness of 4-6 $\mathrm{m}$ and above has negative effects on the larch renewal, as it melts only by mid-July, which leads to a significant reduction in the vegetation period in such areas. In snowy habitats, the emerged undergrowth survives to 15-25 years of age dying as a result of the insufficient vegetation period (Fig. 4a).

Due to the fact that the structure of sparse larch forests in the ecotone constantly changes in space and time, the location of multi-snow habitats changes as well.
In the event that the deposition of a snowdrift has moved to a forest stand, in which the height of the trees exceeds 5-6 m, the trees will not die out, since the vegetation of shoots not covered by snow begins simultaneously with the trees growing in habitats having a small amount of snow. In habitats abounding in snow, tall trees begin to vegetate when the snow cover thickness is less than $1,5-2 \mathrm{~m}$ at the base of trunks (Fig. 4b).

Narrow annual rings, shorter needles, and smaller cones are formed in such trees. The absence of branches up to the maximum height of the snow cover is a characteristic feature of such trees; it is due to the fact that they break off under the weight of dense snow that settles down during its melting (Fig. 4b). Considering that snowdrifts of up to $6 \mathrm{~m}$ thick accumulate on the leeward side of sparse larch forests, treeless strips of up to 50-100 m wide are formed here occupied by lawns of various grasses and tundra biocoenoses (Fig. 4c). Alternation in the ecotone of forest-tundra and tundra-meadow biocoenoses oriented perpendicular to the prevailing wind direction is observed on the eastern slopes of the Rai-Iz mountain massif and Chernaya mountain. On the steep slopes of the Rai-Iz mountain massif, snow avalanches (Fig. 4d) and mudflows are observed in snowy years, which destroy tree vegetation lowering the uPer boundary of its growth. During breaking up of ice on a river, damage to the soil cover and woody vegetation is possible (Fig. 4e). 
4. The chemical composition of rocks and rockiness of the habitat

The chemical composition of rocks has a great influence on the structure of the vegetation cover. The Rai-Iz mountain massif con- sists of ultrabasic rocks - peridotites and dunites of normal alkaline composition, on which alder does not grow. There is no mycorrhiza on its roots. Alder is nourished with moisture and miner- als by nodule bacteria that cannot tolerate an alkaline environment. A band of rocks represented by gabbro, which fine-grained soil has an acidic medium, extends along the eastern periphery of the Rid-Iz

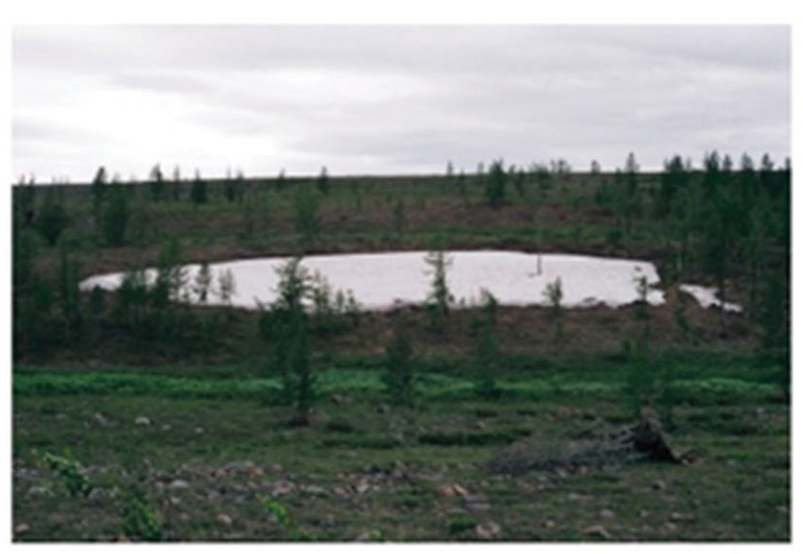

$a$

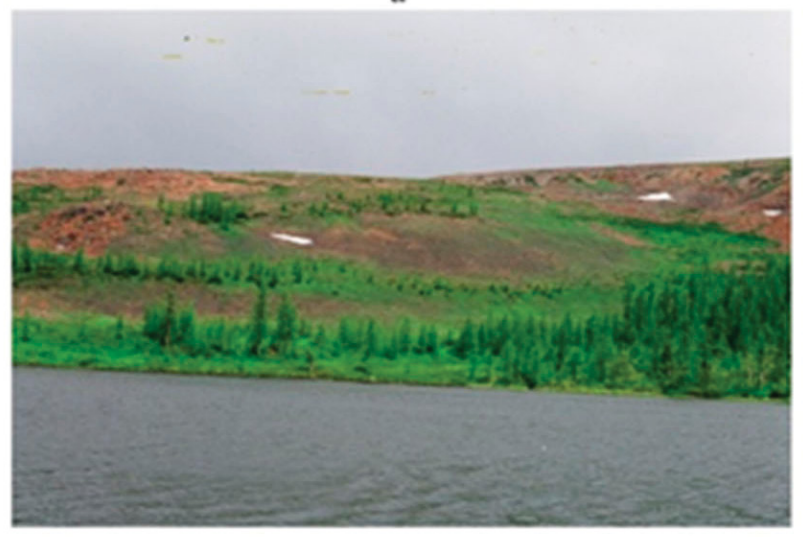

c

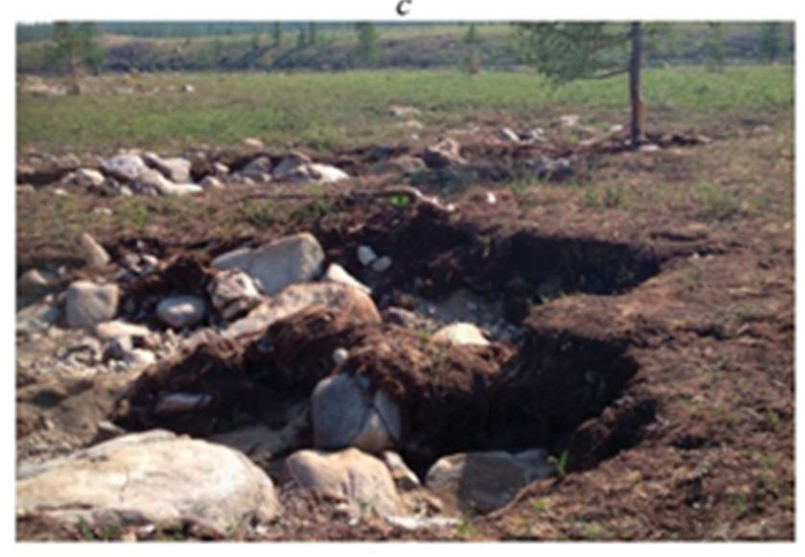

e

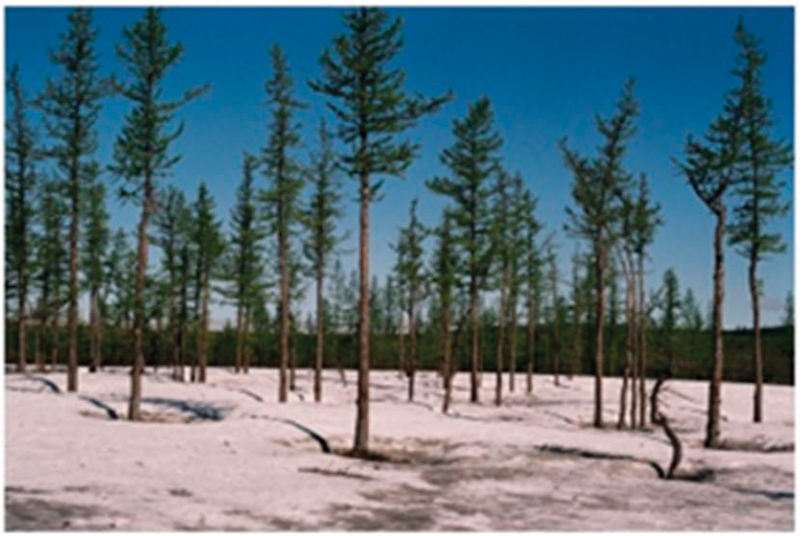

$b$

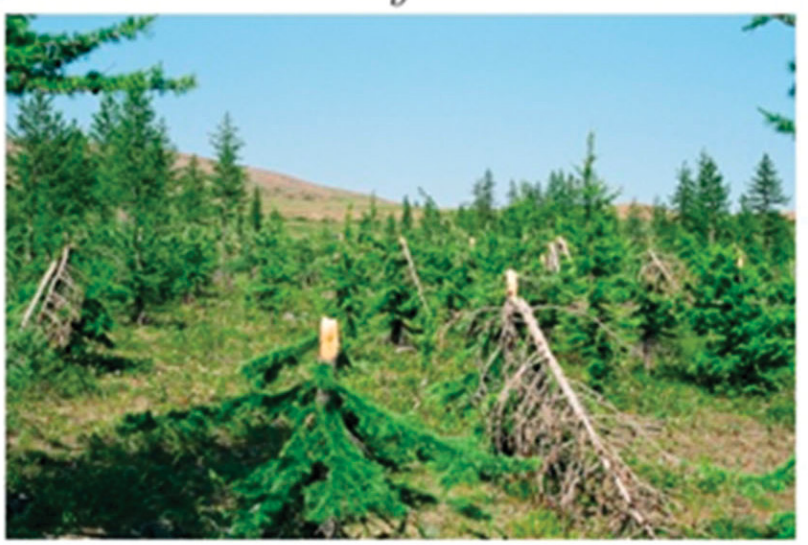

$d$

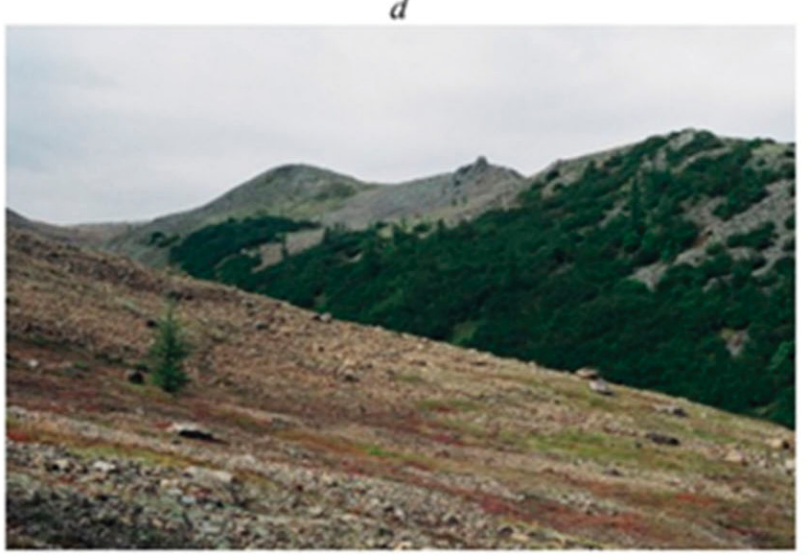

$f$

Fig. 4. The effect of snow on woody vegetation:

$a$ - the formation of powerful snowdrifts of snow delays the onset start of vegetation period; $b$ - vegetation period for the trees in areas covered with snow; $c$ - the formation of treeless strips as a result of the deposition of snowdrifts of up to $6 \mathrm{~m}$ thick; $d$ - the impact of an avalanche. Damage to the soil cover and trees during breaking up of ice on a river; $e$ - the influence of the chemical composition of rocks on the species composition of woody vegetation; $f$-alder on crystalline schists (in the far-distance view), Siberian larch on peridotites (in the short-distance view) 
peridotite massif. Dense thickets of alder grow on well-moistened acidic soils, which rise higher along the slope compared to larch (Fig. 4f).

On steep slopes covered with large rock fragments, the uPer tree line of sparse larch forest is sharply reduced. On the north-eastern slope of the Rai-Iz mountain massif, it drops to $100 \mathrm{~m}$ above sea level. Only solitary larches, which are settled on microsites where small amounts of fine-grained soil accumulate between large stone blocks, grow above it.

\section{Larch seed production and} dissemination

Siberian larch in the Polar Urals bears fruit almost annually. In harvesting years, up to 1 thousand cones can be generated in large mature trees. The preservation of cones in the tree crown for several years is a characteristic feature of seed production. But the most unusual is that the seed liberation from cones is carried out only next year. Cones formed in the summer period go wet and immature in the winter, with their covering scales being closed. In the winter, the cones dry out, and when warm weather comes up to the next year (up to $10-15$ degrees), the covering scales open and the seeds fly out even with a light wind. The seed liberation begins in early June and lasts until the end of July. Since the seeds are heavy, they fly away from the tree only up to $40-60 \mathrm{~m}$. At this time, there is no snow cover, so the seeds get stuck in the ground cover and do not spread further. This is evidenced by the presence of abundant larch undergrowth near seed trees.

\section{Phytocoenotic factors (large} shrubs)

A large shrub, in particular, alder, is widespread in the research area, especially on the eastern slope of Chernaya mountain. Here, it grows mainly along the hollows of the drain, where abundant flowing moisture is present. An alder tree of up to 3-4 m high forms dense clumps of trees under which sparse grassy vegetation and green mosses grow. Since the alder canopy prevents the penetration of sunlight, this adversely affects larch undergrowth. Therefore, only solitary larches grow in the alder forest. They can be seen in alder in the far-distance view of Fig. 4f. As mentioned above, alder does not grow on mountain slopes composed of ultrabasic rocks (peridotites and dunites), and here, it is not a competitor to larch and other plant species of ground vegetation (Fig. 4f).

\section{Needle cast of Sibirian larch} and Sibirian spruce

The activity of the pathogenic agent of needle cast has noticeably increased in the Polar Urals over the past 15 years. It settles on needles of Sibirian larch and Sibirian spruce, mainly in the surface branches covered with snow in the winter. At the beginning of the vegetation period, it is not visible on the last year's spruce needles and on the current year's larch needles. But at the end of the vegetation period, the needles are covered with small fruit bodies of gray color leading to premature yellowing and dying of the needles (Fig. 5a). We did not observe such fungal damage to needles in the 1960s. The modern activity of pathogenic agent of needle cast seems to be caused by intense climate warming that has observed in the last 15-20 years.

\section{Damage to trees by reindeer} and mouse-like rodents

Small reindeer herds are grazed in our research area in the summer and winter. After the railway from Seyda station to the village of Labytnangi had been constructed in 1947, the run of reindeer herds along the eastern foothills of the Rai-Iz mountain massif and Chernaya mountain sharply decreased that led to better preservation of larch undergrowth. It is difficult for reindeers, especially on the ice-crusted ground, to dig out a dense snow cover to eat plants that form the ground cover (mosses, lichens, rags, and small shrubs). Therefore, they gnaw the shoots round young larches, the peaks with shoots and bark which are above the level of the snow cover (Fig. 5b). Some such larches dry out . There are moraine fields consisting of peridotites on the eastern macroslope of the Rai-Iz mountain massif and Chernaya mountain; they are exposed to strong winds. As a result, there is poor vegetation unsuitable for reindeer grazing here.

We had to observe such an interesting phenomenon in the research area, like the ringing of larch trunks with mouse-like rodents in the win- 
ter, from the surface of the ground to the surface of the snow cover (Fig. 5c). They gnaw out and eat the bark and bast, rising along the paths inside the snow cover to a height of up to 2-3 m. If gnawing occurs on all sides of the trunk (ringing), this trunk dries up in the next year's summer. Such damage to the larch was observed during the years of mass reproduction of mouse-like rodents, for example, in the winter of 2000-2001.

\section{Anthropogenic factors}

Anthropogenic factors significantly affect the woody vegetation of the Polar Urals. Until the 1950 s, the main damages to larch occurred under the influence of grazing herds of domestic reindeer (Fig. 6a, 6b). In subsequent years, in connection with the laying of the railway along the Sob River valley, the migration routes of reindeer

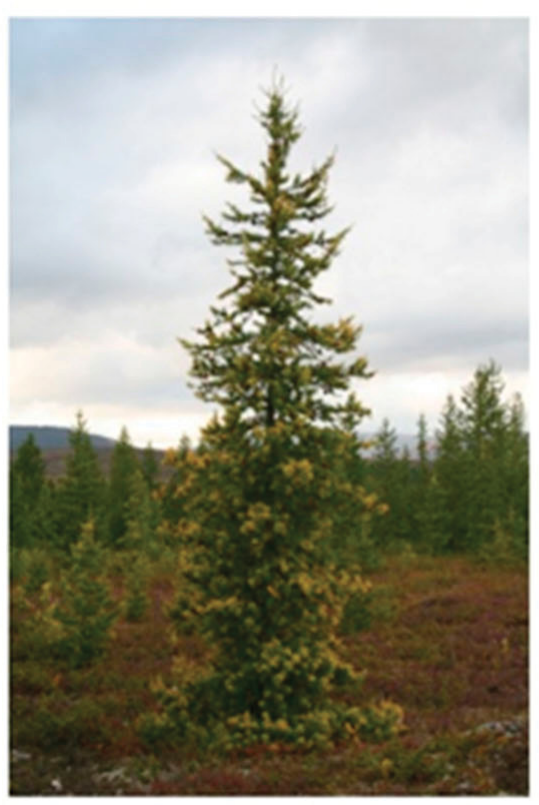

$a$ herds shifted to the north. Until 1947, geological studies were insignificant, and the transportation of cargos and people was carried out by horses.

Since the 1950s, the intensity of geological exploration increased dramatically, and all-terrain vehicles and tractors were widely used to transport cargos. Using caterpillar vehicles led to significant deterioration of the tundra and to a lesser extent woody vegetation (Fig. 6c). Traces of the passage of all-terrain vehicles are preserved for a long time; their overgrowing with vegetation occurs slowly. Deterioration of the vegetation cover in moist and boggy habitats is especially noticeable (Fig. 6d). At the sites of geological parties' stations, trees were cut down for fuel and other economic purposes (Fig. 6e).

An earth-road was laid from the village of Harp to the top of the

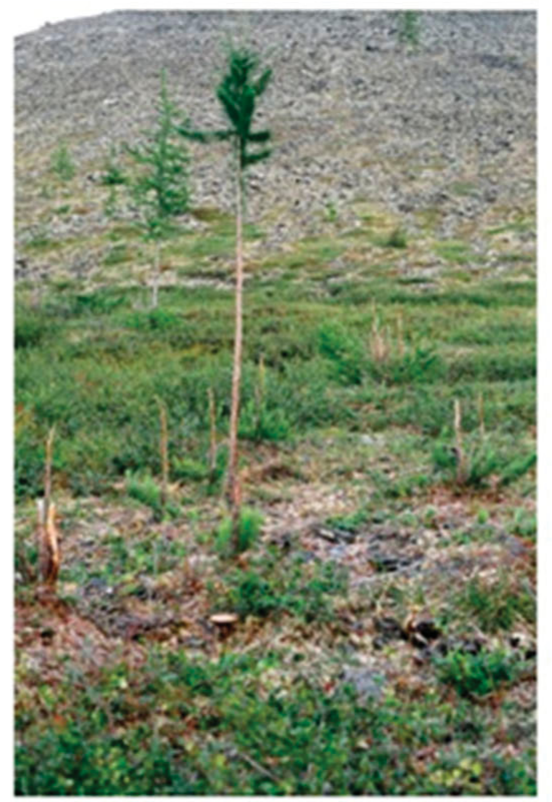

b
Rai-Iz mountain massif in our research area in the 2000s, through which heavy trucks transport chromite ore (Fig. 6f). When such cars pass along the road, a cloud of dust rises and then sediments at a distance of up to $100 \mathrm{~m}$ from the road. As a result, vegetation, including wood one, is covered with a thick layer of dust that complicates photosynthesis in plants.

\section{Conclusion}

The factors affecting the woody vegetation growing in the forest-tundra ecotone on the eastern macroslope of the Polar Urals in the Sob River basin are diverse. Natural factors (such as air and soil temperature, wind regime, snow cover, steepness and rockiness of the slope, and chemical composition of rocks) still prevail. The influence of anthropogenic factors is less significant. Grazing and running herds of

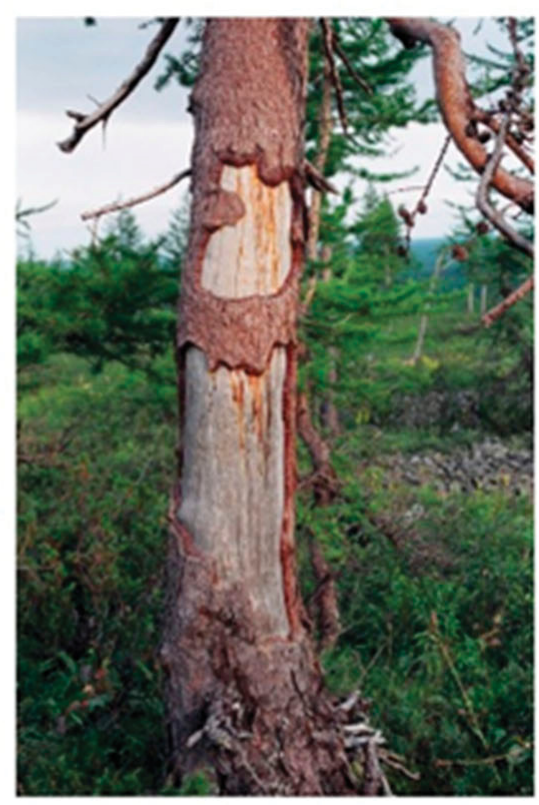

Fig. 5. Damage to larch needles by needle cast $(a)$; damage to tree trunks by reindeers $(b)$ and mouse-like rodents $(c)$ 
domestic deers in the summer and in a period having a small amount of snow was the main one until 1945. After the railway along the Sob duct having been constructed in 1947 , the intensity of the influence of anthropogenic factors increased significantly. The main ones are as follows: a sharp increase in geological exploration using caterpillar vehicles, laying earth-roads, mining, increasing the intensity of walking tours and research scientific work. In this regard, it is necessary to strengthen the work on the organization of nature reserves with the purpose of protecting unique tundra and forest-tundra biocoenoses.
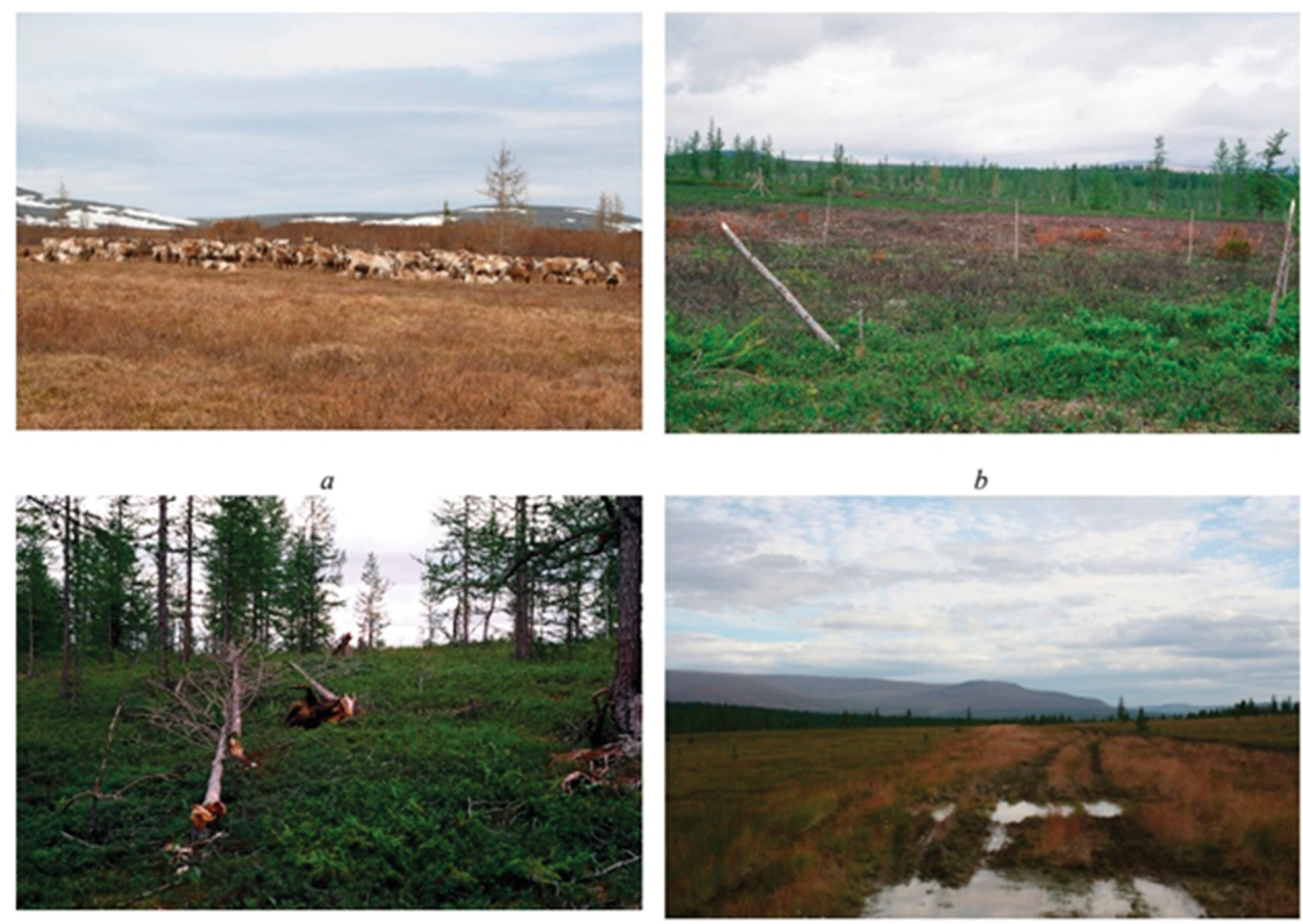

$c$
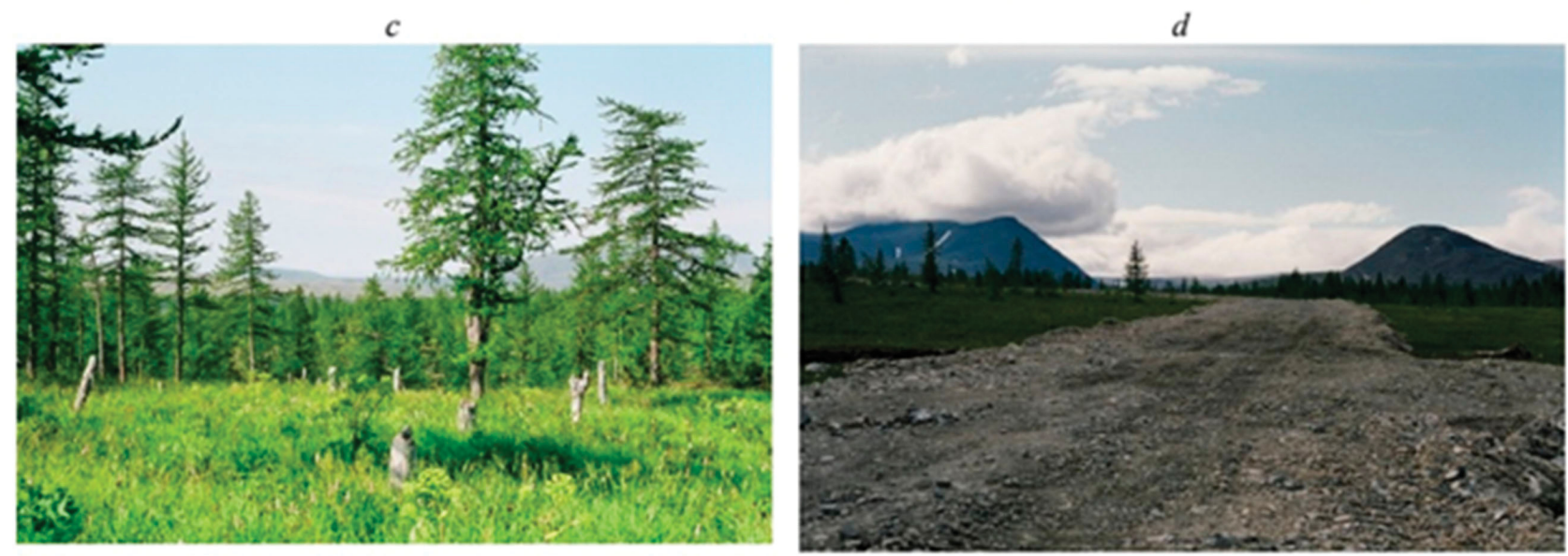

$e$

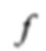

Fig. 6. The main types of anthropogenic impacts in the research area.

The effect of grazing domestic reindeers $(a)$ and the corral for reindeers $(b)$. Examples of anthropogenic impacts: the passage of all-terrain vehicles $(c)$; the road of all-terrain vehicles $(d)$; the site of geological stations $(e)$; earth-roads $(f)$ 


\section{Acknowledgements}

The study was carried out with the financial suPort the Ministry of Science and Higher Education of the Russian Federation (project FEUG-2020-0013). We thank
Anna P. Mikhailovich for assistance with created of spatial datasets for study area and the points of photography, as well as for preparing fig. 1 and for the photos presented in Fig. 4C, Fig. 5e and Fig. 7f. This part of work was suPorted by the Russian Foundation for Basic Research (project No. 18-34-00803 mol_a).

\section{Bibliography}

1. Shiyatov S. G. Rates of Change in the UPer Treeline Ecotone in the Polar Ural Mountains / Pages. 2003. - Vol. 11(1). - P. 8-10.

2. Shiyatov S. G., Terent'ev M. M., Fomin V. V., Zimmermann N. E. Altitudinal and horizontal shifts of the uPer boundaries of open and closed forests in the Polar Urals in the 20th century // Russian Journal of Ecology. - 2007. - Vol. 38(4). - P. 223-227.

3. Shiyatov S. G., Mazepa V.S. Contemporary expansion of Siberian larch into the mountain tundra of the Polar Urals // Russian Journal of Ecology. - 2015. - Vol. 46(6). - P. 495-502. - URL: https://doi.org/10.1134/ S1067413615060168

4. Fortin J. A., Fisher J. T., Rhemtulla J. M., Higgs E. S. Estimates of landscape composition from terrestrial oblique photographs suggest homogenization of Rocky Mountain landscapes over the last century // Remote Sensing in Ecology and Conservation. - 2019. - Vol. 5(3). - P. 224-236. - URL: https:// doi.org/10.1002/ rse2.100

5. Kullman L. Structural Change in a Subalpine Birch Woodland in North Sweden During the Past Century // J. Biogeogr. - 1991. -Vol. 18(1). - P. 53-62. - URL: https://doi.org/10.2307/2845244

6. Kullman L. Rapid recent range-margin rise of tree and shrub species in the Swedish Scandes // J. Ecol. 2002. - Vol. 90. - P. 68-77.

7. Kullman L. Tree line population monitoring of Pinus sylvestris in the Swedish Scandes, 1973-2005: implications for tree line theory and climate change ecology // J. Ecol. - 2007. - Vol. 95. - P. 41-42. - URL: https://doi.org/https://doi.org/10.1111/j.1365-2745.2006.01190.x

8. Mikhailovich A. P., Fomin V. V. Shiyatov S. G. Photographic atlas of the Polar Urals landscapes in downstream Yengaiu and Kerdomanshor rivers in the second half of the XX - XXI centuries. - Yekaterinburg : USFEU. - 2016. -97 p.

9. Holtmeier F.-K., Broll G. Treelines - A Proaches at Different // Scales. Sustainability. - 2017. - Vol. 9 (5). P. 808. - URL: https://doi.org/https://doi.org/10.3390/su9050808

10. Kaim D. Land cover changes in the Polish Carpathians based on repeat photography // Carpathian Journal of Earth and Environmental Sciences. - 2017. - Vol. 12 (2). - P. 485-498.

11. Sanseverino M. E., Whitney M. J., Higgs E. S. Exploring Landscape Change in Mountain Environments With the Mountain Legacy Online Image Analysis Toolkit // Mountain Research and Development. - 2016. Vol. 36 (4). - P. 307-416. - URL: https://doi.org/10.1659/mrd-journal-d-16-00038.1

12. Bayr U., Puschmann O. Automatic detection of woody vegetation in repeat landscape photographs using a convolutional neural network // Ecological Informatics. - 2019. - Vol. 50. - P. 220-223. - URL: https:// doi.org/10.1016/j.ecoinf.2019.01.012 